\title{
GENETIC VARIATION AS A POSSIBLE EXPLANATION FOR THE HETEROGENEITY OF PAIN IN TENDINOPATHY: WHAT CAN WE LEARN FROM OTHER PAIN SYNDROMES?
}

\author{
Nonhlanhla S. Mkumbuzi ${ }^{A, B, D}$ \\ Health through Physical Activity, Lifestyle and Sports Research Centre, Division of Physiological Sciences, Department of Human Biology, \\ University of Cape Town. Anzio Road, Observatory 7935, Cape Town, South Africa \\ International Federation of Sports Medicine (FIMS) Collaborative Centre of Sports Medicine, South Africa \\ ORCID: 0000-0002-4982-0662 | e-mail: nonhlanhla.mkumbuzi@uct.ac.za
}

Michael Posthumus ${ }^{A, D}$

Health through Physical Activity, Lifestyle and Sports Research Centre, Division of Physiological Sciences, Department of Human Biology, University of Cape Town. Anzio Road, Observatory 7935, Cape Town, South Africa

High Performance Centre, Sports Science Institute of South Africa, Boundary Road, Newlands, 7725, Cape Town, South Africa ORCID: 0000-0002-8806-8805 | e-mail: mposthumus@ssisa.com

\author{
Alison V. September, D \\ Health through Physical Activity, Lifestyle and Sports Research Centre, Division of Physiological Sciences, Department of Human Biology, \\ University of Cape Town. Anzio Road, Observatory 7935, Cape Town, South Africa \\ International Federation of Sports Medicine (FIMS) Collaborative Centre of Sports Medicine, South Africa \\ ORCID: 0000-0003-0950-286X | e-mail: alison.september@uct.ac.za
}

\section{Malcolm Collins $\mathrm{A}, \mathrm{D}, \mathrm{E}$}

Health through Physical Activity, Lifestyle and Sports Research Centre, Division of Physiological Sciences, Department of Human Biology, University of Cape Town. Anzio Road, Observatory 7935, Cape Town, South Africa International Federation of Sports Medicine (FIMS) Collaborative Centre of Sports Medicine, South Africa ORCID: 0000-0002-2564-0480 | e-mail: malcolm.collins@uct.ac.za

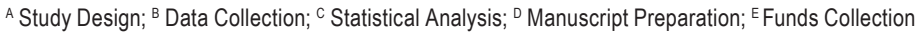

Ahstract The mechanisms of pain in tendinopathy are unclear. Current theories implicate tendon structural changes, neovascularisation, inflammation or changes in central pain processing. As with other types of musculoskeletal pain, tendon pain has high interindividual variability, which could be attributed to genetic variation. Notably, the association between certain genetic polymorphisms and other pain syndromes is well established in the literature. Therefore, the investigation of the mechanisms of pain in tendinopathy could extend to include genetic variation as a possible explanation for the clinical features of tendon pain. This review summarises the current knowledge on genetic contributors to other pain syndromes and highlights findings that are relevant to chronic tendon pain. In particular, based on the current hypotheses on the possible sources of tendon pain, it focuses on findings that relate to genes that encode structural connective tissue components, inflammatory markers, ion channels and catecholamines and how they may relate to chronic tendon pain. In the absence of a definitive mechanism of tendon pain, an 
a priori genetic approach that is guided by these current hypotheses may help elucidate the mechanisms of tendon pain which may allow a more rational approach to research and treatment.

Key WOrlls tendon pain, genetics, extracellular matrix genes, inflammation genes, COMT

\section{Introduction}

Tendinopathies are common in recreational and professional athletes (Lagas et al., 2020), and in certain occupations (Owens et al., 2013). The main presenting complaint in tendinopathy is pain of insidious onset (Silbernagel, Hanlon, Sprague, 2020), which is not proportionate to tissue damage (Docking, Ooi, Connell, 2015), is difficult to manage (Cook, Purdam, 2009) and persists even after resolution of other functional outcome measures (Van Ark et al., 2018). This is not surprising because its source and/or mechanisms are currently not fully understood. Consequently, several theories have been proposed explaining the potential sources of pain in tendinopathy, with no consensus on what the exact mechanisms of pain are in tendinopathy. Current theories implicate structural changes in the tendon (Bakkegaard, Johannsen, Højgaard, Langberg, 2015), neovascularisation (Mousavizadeh et al., 2014), inflammation (Abate et al., 2009; Battery, Maffulli, 2011; Dean et al., 2015), biochemical changes (Lian et al., 2006; Schizas et al., 2012), ion channel abnormalities (Rio et al., 2014), as well as alterations in central pain modulation (Plinsinga, Brink, Vicenzino, van Wilgen, 2015; Tompra, Van Dieen, Coppieters, 2016). The aetiology of chronic tendon pain remains poorly understood and most likely presents with its own unique clinical features. However, it is not implausible to assume that chronic tendon pain shares a proportion of its physiology (Caneiro et al., 2020) and burden (Mc Auliffe et al., 2017; Mkumbuzi et al., 2020) with other types of chronic painful musculoskeletal (MSK) conditions.

As with other chronic painful MSK conditions, tendon pain responses are characterised by robust interindividual variability in sensitivity and susceptibility (Fillingim, Wallace, Herbstman, Ribeiro-Dasilva, Staud, 2008), and mounting evidence suggests that a significant portion of pain variability can be explained by genetics (Bjorland, Moen, Schistad, Gjerstad, Røe, 2016; Foulkes, Wood, 2008; Veluchamy, Hebert, Meng, Palmer, Smith, 2018). It is interesting that the estimated heritability of nociceptive and analgesic sensitivities is as much as $76 \%$ (Chidambaran, Gang, Pilipenko, Ashton, Ding 2019; Diatchenko et al., 2005; Peters et al., 2013; Ruau et al., 2012). Consequently, several genetic polymorphisms have been associated with specific pain syndromes (Foulkes, Wood, 2008), pain perception and analgesic use (Hooten, Hu, Cunningham, lii, 2019; Olesen et al., 2018; Packiasabapathy, Horn, Sadhasivam, 2019; Wang, Wei, Xiao, Chang, Zhang, 2019), and response to physiotherapy treatment (Govil et al., 2020).

The aim of this narrative review was therefore, to summarise the current knowledge on genetic contributors to chronic pain in other pain syndromes, which could potentially also be considered for chronic tendon pain. Based on the current hypotheses on the possible sources of tendon pain, this narrative review therefore focused on findings that relate to genes that encode structural connective tissue components, inflammatory markers, ion channels and catecholamines. In the absence of a definitive source and/or mechanism of pain in tendinopathy, an a priori genetic approach guided by these current hypotheses may assist in identifying potential biological mechanisms to be considered for tendon pain which may also inform a more rational approach to its research and development of treatment paradigms. 


\section{The structural changes hypothesis: Extracellular matrix components and regulators}

The COL11A1 and COL11A2 genes encode the a1 and a2 chains of the minor fibrillar type XI collagen. Individuals with knee osteoarthritis (OA) who had a COL11A2 rs16868943 GG genotype had on average a higher heat pain tolerance (Ho et al., 2017). Additionally, an increased risk of developing OA was reported in the COL11A2 knockout mouse model (Lapvetelainen et al., 2002). While COL11A2 has not itself been associated with OA risk in humans, variations in the COL11A1 gene have been implicated with risk (Raine, Dodd, Reynard, Loughlin, 2013). Additionally, mutations in the COL11A2 gene have also been associated with osteochondroplasia (Avcin et al., 2008) and non- ocular Stickler's syndrome (Vuoristo, Pappas, Jansen, Ala-Kokko, 2004), both of which share clinical features with OA. It is tempting to speculate that COL11A2 might not only be associated with risk of developing these conditions but potentially in the development of the associated pain.

Although the genotypes were not independently associated, the inferred T-C-T haplotype constructed from the COL11A1 rs3753841 (T/C), COL11A1 rs1676486 (C/T) and COL11A2 rs1799907 (T/A) was previously associated with increased risk of Achilles tendinopathy in two independent populations (Hay et al., 2013). In addition, the COL11A1 rs3753841 TT genotype and the inferred T-C haplotype constructed from COL11A1 rs3753841 and rs1676486 was previously associated with carpal tunnel syndrome (CTS) (Dada, Burger, Massij, de Wet, Collins, 2016). COL11A1 rs3753841 was also independently associated with elbow tendon pathology (Alakhdar Mohmara et al., 2020). Although these studies did not specifically investigate the association of the type XI collagen gene variants with tendon pain, this should be explored in future work. It would also be interesting to investigate the possible association of other collagen genes with tendon pain.

The matrix metalloproteinases (MMPs) are a family of enzymes that have been implicated in pain. Individuals with a MMP1 rs1799750 GG genotype on average presented with higher temporomandibular joint pain scores (Planello et al., 2011). This finding was replicated in an independent cohort of low back pain patients where individuals with the GG genotype also presented with higher pain scores on the McGill Pain Questionnaire as well as more disability (Jacobsen et al., 2013). In addition, expression of MMP10 mRNA was significantly increased in surgical patients with pain compared to pain free controls in a study by Richardson, Doyle, Minogue, Gnanalingham, Hoyland (2009). Furthermore, in animal models, MMP2 expression was elevated in models of neuropathic pain (Miranpuri et al., 2016). Additionally, the roles of MMPs, in particular MMP-2 and MMP-9, in facilitating inflammatory pain have been demonstrated in various studies where these enzymes are required in the early and late stages of neuropathic pain development (Ji, Gereau, Malcangio, Strichartz, 2009). Interestingly, their inhibition led to pain relief (Li et al., 2016) and decreased mechanical allodynia in rodent models (Kular et al., 2012). Future studies should therefore also specifically investigate the possible association of variants within the family of MMP and tissue inhibitors of metalloproteinases (TIMP) genes, which have previously been associated with Achilles tendinopathy (Raleigh et al., 2009, El Khoury, Ribbans, Raleigh, 2013; Kang et al., 2019), with tendon pain.

The caspases (CASP), which are protease enzymes involved in apoptosis and inflammation (Berta, Lee, Park, 2017; Joseph, Levine, 2004), are another family of enzymes that are implicated in pain. CASP-6 regulates chronic pain via microglial inflammatory signalling, most likely through TNF-a secretion (Berta et al., 2017). Additionally, inhibition of CASPs-1, $-2,-3,-8$ and -9 attenuated pain related behaviour in HIVIAIDS and cancer neuropathy models (Joseph, Levine, 2004). This suggests that caspase signalling pathways contribute to pain. This is further demonstrated by an association between the -1263 CASP-9 rs4645978 promoter variant with low back pain (Mu, Ge, Zuo, Chen, Huang, 2013). In this study, carriers of the minor $\mathrm{G}$ allele were overrepresented in the pain 
group compared to their pain-free compatriots. Similarly, Guo et al. (Guo, Liu, Zhang, Guo, Wu, 2011) showed an association between the -1263 CASP-9 rs4645978 GG genotype with discogenic low back pain. Since variants within CASP8 have been associated with tendinopathy in some (Seale et al., 2020), but not all studies (Kang et al., 2019), future work should also consider it and other CASP genes as candidates for association with tendon pain.

\section{Tendon pain as a channelopathy: Ion channels}

Ion channels are very important in the pain pathway, where they manage the generation and processing of pain signals. Sodium, potassium and calcium channels are the main ion channels in neuronal transmission in nociceptors and have been firmly implicated in human pain disorders (Waxman et al., 2014). In particular, voltagegated sodium channel 1.7 (Nav1.7) is expressed in nociceptors and amplifies subthreshold stimuli. Unsurprisingly, a number of clinical effects such as primary erythermelalgia, paroxysmal extreme pain disorder and congenital insensitivity to pain have been observed in individuals with gain of function and loss of function Nav1.7 mutations, respectively (Estacion et al., 2009; Reimann et al., 2010). In addition to these rare diseases that result from high impact mutations, variants in the gene encoding the a subunit of the sodium voltage gated channel 1.7 (SCN9A) were also associated with subtle effects in modulating risk and severity of pain in acquired pain conditions. For instance, the SCN9A rs6746030 variant results in an amino acid substitution of arginine to tryptophan at codon 1150 of the a subunit of Nav1.7, which enhances cell excitability of dorsal root ganglia (Estacion et al., 2009). Some studies have demonstrated that the minor rs6746030 A allele (tryptophan substitution) was associated with increased pain reports in individuals with OA, sciatica and phantom limb pain (Reimann et al., 2010) as well as postoperative pain (Duan et al., 2016) and small fibre neuropathy (Hoeijmakers, Merkies, Gerrits, Waxman, Faber, 2012). Additionally, functional characterisation of two rare non-synonymous mutations of SCN9A, methionine to threonine substitution (rs201561928) and threonine to isoleucine (rs200470541) at codons 1863 and 1607, respectively demonstrated gain of function changes consistent with an increase in neuronal excitability in a diabetic neuropathy cohort (Blesneac et al., 2018). Similarly, rare mutations in the SCN10A and SCN11A genes, encoding Nav1.8 and Nav1.9, respectively have also been shown to contribute to inflammatory and neuropathic pain (Huang et al., 2013) and familial episodic pain (Zhang et al., 2013), respectively (Table 1). However, other authors have not been able to replicate these results in independent cohorts (Holliday et al., 2012). The potential relevance of Nav to pain in tendinopathy was demonstrated by Gammaitoni et al. (2013) who reported success with topical lidocaine in managing patellar tendinopathy pain. As lidocaine provides pain relief by blocking Nav channels, their results suggest that peripheral Nav channels play a role in tendon pain; therefore, variants in sodium channels may well affect the pain profile in tendinopathy.

Variants in genes encoding other ion channels such as voltage gated potassium channels (Kv) and voltage gated calcium channels (Cav) have also been associated with chronic painful conditions. The rs734784 variant in potassium voltage-gated channel delayed rectifier subfamily S, member 1 (KCNS1) was associated with higher pain in healthy controls and in phantom limb pain, however, this variant did not associate with post mastectomy pain (Costigan et al., 2010). In addition, a number of variants in voltage gated, inward rectifying and two pore potassium channel genes were associated with risk and severity of persistent pain following surgery (Chidambaran, Gang, Pilipenko, Ashton, Ding, 2019) (Table 1). Voltage gated $\mathrm{Ca}^{2+}$ channels constitute the main pathway for depolarisation mediated $\mathrm{Ca}^{2+}$ influx into neurons. Genes that encode these $\mathrm{Ca}^{2+}$ channels have been implicated in painful conditions. For example, Cacna2d3, the gene that codes for the a253 subunit of the voltage dependent calcium- 


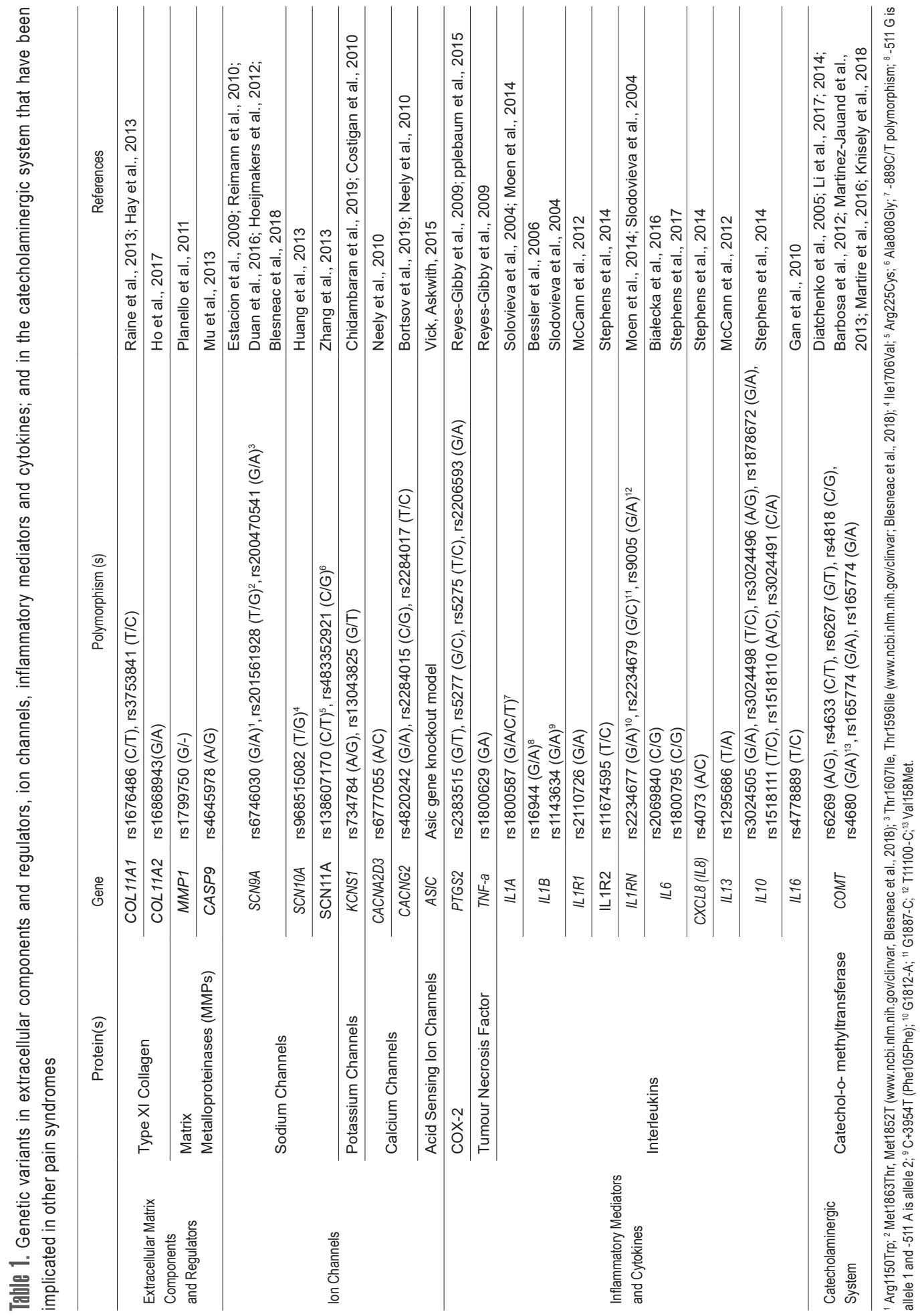


channel complex, has been associated with thermal pain-related behaviour in animal studies (Neely et al., 2010). In healthy volunteers, the rare CACNA2D3 rs6777055 C allele was also associated with reduced acute thermal pain while individuals with a CC genotype showed reduced risk for chronic back pain post discectomy (Neely et al., 2010). Additionally, Cacng2 variants (Cacng2 encodes for the $y 2$ transmembrane AMPA receptor protein stargazin) affect susceptibility to chronic pain after nerve injury in mice (Neely et al., 2010). In humans, an association was observed between increased susceptibility to pain after mastectomy and the A-C-C haplotype constructed from the CACNA2 rs4820242, rs2284015, and rs2284017 intronic variants (Bortsov et al., 2019).

Other ion channels whose expression may be modulated in tendinopathy are acid sensing ion channels (ASICs). The role of ASICs in pain has been demonstrated in rodent studies where Asic gene knockout mice were resistant to mechanical hyperalgesia (Vick, Askwith, 2015) as well as being linked to migraine in humans (Dussor, 2015). ASICs have also been associated with other painful conditions that, much like tendinopathy, involve acidosis, inflammation and ischaemia (Rio et al., 2014).

\section{The inflammatory hypothesis: Inilammatory mediators and cytokines}

A number of inflammatory mediators such as cytokines are also important in the pathology of painful tendinopathy. These cytokines include TNF-a, FGF, TGF-p and the interleukin family (Dakin, Dudhia, Smith, 2014). In particular, IL-1a, IL-ip and IL-33, with a signalling pathway through the activation of mitogen activated protein kinases (MAPKs), stimulate mediators of inflammation causing the onset of pain and extracellular matrix (ECM) breakdown (D'Addona, Maffulli, Formisano, Rosa, 2017). Research in other chronic painful conditions has shown some associations between cytokine gene variants and pain. For instance, a study on lung cancer patients showed that certain genotypes for PTGS2, which encodes Cyclooxygenase- 2 (COX-2), and Tumor Necrosis Factor alpha (TNF-a) polymorphisms are protective and permissive to pain, respectively (Reyes-Gibby et al., 2009) (Table 1). However, the PTGS2 G-G-T-A haplotype constructed from rs2383515, rs5277, rs5275 and rs2206593 was associated with post-treatment pain following endodontic treatment (Applebaum, Nackley, BairMaixner, Khan, 2015). In a study of women with breast cancer, carriers of the minor A allele of IL1R1 rs2110726 reported less breast pain while those with the minor A allele of IL13 rs1295686 had higher pain scores (McCann et al., 2012). Stephens et al. (2014) also showed that IL1R2 rs11674595 and the IL10 haplotype A8 (Table 1) were associated with persistent postoperative pain following breast cancer surgery. In other work, Stephens and colleagues also showed that variants in IL6, CXCL8 (IL8), and TNF are associated with the development and maintenance of mild persistent breast pain after breast cancer surgery (Stephens et al., 2017) (Table 1).

A study from China on females diagnosed with endometriosis also showed an increased representation of the C allele of rs 4778889 in the IL16 gene compared to healthy controls and particularly in those with higher selfreported pain (Gan et al., 2010). These results were not replicated among women from a study in Iran (Azimzadeh, Khorram Khorshid, Akhondi, Shirazi, 2016). Individuals carrying at least one $G$ allele of IL6 rs1800795 also reported higher pain scores in the postoperative period following total hip replacement (Białecka et al., 2016). Additionally, simultaneous carriage of other interleukin-1 variants, IL-1 RNA and IL-1a has been shown to increase the pain intensity and duration in chronic low back pain (Solovieva et al., 2004) (Table 1). This suggests that IL-1a and IL-1^ variants may promote or prolong low back pain. Furthermore, variants in IL1A rs1800587 affected pain scores and pressure pain threshold in a cohort of patients with lumbar radicular pain. In this cohort, the rs $1800587 \mathrm{~T}$ allele was associated with an enhanced promoter activity resulting in increased gene expression which enhances the 
release of IL-1a and hence the inflammatory response and pain report (Schistad, Jacobsen, Røe, Gjerstad, 2014). Furthermore, an association between the IL1A rs 1800587 variant and pain intensity was observed in a cohort from Finland, of middle-aged men with low back pain (Solovieva et al., 2004). Similarly, Moen, Schistad, Rygh, Re, Gjerstad (2014) showed that in lumbar radicular pain, patients with the IL1A rs1800587 T allele in combination with the IL1 RN rs2234677 A allele had more pain and a slower recovery than other patients. Bessler et al. (2006) did not, however, show a relationship between postoperative pain or morphine use and IL1B variants in a cohort of women undergoing transabdominal hysterectomy (Table 1).

Although the association with pain was not investigated, several studies have investigated the association of interleukin gene variants with risk of tendinopathy. In one, the AA genotype of IL6R rs2228145 (C/A) was associated with reduced risk of developing CTS in a South African cohort (Burger, de Wet, Collins, 2015). In another, while variants within the IL-1^, IL-6 and IL-1RN genes were not independently associated with Achilles tendinopathy risk, when found with the COL5A1 rs12722 (C/T) variant, they were collectively implicated in modulating risk of Achilles tendinopathy (September et al., 2011). It is interesting to note that a study by Suijkerbuijk et al. (2020) implicated variable cytokine expression, specifically ILip, IL6 and IL-6 Receptor, in the context of a genetic dependent risk model using fibroblast cells. Taken collectively, the importance of the inflammatory pathway in tendinopathy is growing, it would be of interest to further explore the relationship between interleukin genes and tendon pain.

\section{The central pain mechanisms hypothesis: COMT}

Available evidence also suggests that tendon pain may be a result of defective central pain inhibition (Plinsinga et al., 2015; Tompra et al., 2016). The catecholaminergic system plays a crucial role in the facilitation or inhibition of nociceptive transmission (Millan, 1999). Abnormalities in catecholamine physiology are associated with decreased activity of catechol-o-methyltransferase (COMT), an enzyme which inactivates catecholamines. As a result, COMT, the gene that encodes the enzyme, is one of the most frequently studied of pain genes and has been associated with differential pain sensitivity under experimental and pathological conditions (Baumbauer et al., 2020) as well as with anxiety, depression, and other psychological traits that influence the perception of pain (Fernandez-De-Las-Penas et al., 2019).

Most commonly, various studies have demonstrated the association between Val/Met substitution at codon 158 in the COMT gene (rs4680) and numerous pain disorders (Tammimaki, Mannisto, 2012). Individuals homozygous for the Val variant have three to four times higher activity of the COMT enzyme and hence reduced pain sensitivity compared to homozygotes of the Met genotype (Diatchenko et al., 2005) whose variation leads to decreased COMT thermostability, activity and increased pain report in experimentally induced pain (FernandezDe-Las-Penas et al., 2019) and in orofacial pain (Tchivileva et al., 2011). Furthermore, this variant has also been associated with Parkinson's disease related pain (Lin et al., 2017), fibromyalgia pain sensitivity (Barbosa et al., 2012; Martnez-Jauand et al., 2013), depression and experimental pain (Fernandez-De-Las-Penas et al., 2019), and variability in OA pain (Martire et al., 2016).

Other COMT variants such as rs6269, rs4633 and rs4818 were also associated with low back pain related disability in a mixed European cohort; the minor G, $C$ and $G$ alleles of these three polymorphisms were associated with lower baseline disability scores (Omair et al., 2015). Carriers of the rs4818 CC genotype were also overrepresented in a cohort of fibromyalgia from Brazil (Barbosa et al., 2012) and the minor C, G and A alleles of rs4633, rs4818 and rs4680, respectively, were over-represented in other fibromyalgia cohorts though not associated with 
pain (Brenton et al., 2017). COMT rs6267 has also been associated with Parkinson's disease pain wherein the minor T allele presented with higher pain scores (Li, Chen, Yin, Zhang, 2014). In addition, COMT rs165774 showed an association with heat pain; the wild type GG genotype with lower pain threshold (Mladenovic et al., 2018).

In addition, COMT variants have also been associated with chronic post-surgical pain (Lee, Delaney, Keogh, Sleeman, Shorten, 2011) in which individuals carrying the wild type COMT rs4818 CC genotype presented with lower pain scores than those with the $C G$ and $G G$ genotypes following molar extraction. While the high pain A-CC-G haplotype constructed from rs4663, rs4680 and rs6269 and rs4818 was associated with severe pain after breast cancer surgery (Knisely et al., 2018). Additionally, COMT variants have been associated with post-operative analgesic response (Sadhasivam et al., 2014). In the latter study, minor G, C, G and A allele carriers of rs6269, rs4633, rs4818, and rs4680 were three times more likely to require analgesic intervention than homozygotes of the major alleles. COMT haplotypes have also been shown to affect response to analgesia in temporomandibular joint disease (Tchivileva et al., 2011). Some authors have however not replicated these findings (Kambur et al., 2013).

Wang et al. (2019) found no association between rs4680 and chronic post-surgical pain following caesarean section. Additionally, in other cohorts, there were no associations observed between COMT variants and chronic pain conditions such as Parkinson's disease related pain (Li et al., 2014), pain sensitivity in chronic widespread pain (Nicholl et al., 2010), chronic lower back pain (Omair et al., 2015), pain sensitivity in fibromyalgia (Park et al., 2016), vulvodynia (Patanwala et al., 2017) and chronic post-operative pain (Kolesnikov et al., 2013). The HUNT study was also unable to show any associations between COMT genotypes and twelve musculoskeletal conditions in a large Norwegian cohort (Hagen, Pettersen, Stovner, Skorpen, Zwart, 2006). Moreover, no associations were observed between recovery and pain intensity in a European cohort of whiplash injury (Rydman et al., 2017), migraine headache in a cohort from Japan (Takigawa, Kowa, Nakashima, 2017) or pancreatitis in an independent cohort (van Esch et al., 2011). These conflicting results among studies on the association between genetic and clinical variables may reflect the heterogeneity of pain conditions, related to potential subtypes of pain phenotypes, and the small sample sizes of some of the reported studies. It is important to note that three haplotypes of COMT (rs6269, rs4818 and rs4680) account for about 11\% of the variability in pain perception and given the polygenic nature of pain perception, this is a substantial contribution (Diatchenko et al., 2005).This underscores the significant role that COMT likely plays in pain chronification.

Variants in COMT have also been associated with depression and other mood disorders (Femandez-DeLas-Penas et al., 2019). The potential role of the Val/Met variant in pain could be because individuals with the Met/Met genotype of the Val/Met substitution at codon 158 (rs4680) have greater activation of the limbic regions (anterior cingulate cortex-ACC) of the brain in response to emotionally challenging circumstances and negative stimuli such as pain (Smolka et al., 2005) and lower activation of the dorsolateral prefrontal cortex (Egan et al., 2001) when compared to Val/Val. The ACC is a key structure of cortical pain processing that is involved in the affective evaluation of pain as well as anti-nociception (Boadas-Vaello, Homs, Reina, Carrera, Verdu, 2017).

Additionally, Met/Met individuals also have higher pain sensitivity and dysfunctional $p$ - opioid receptor mediated mechanisms in the parahippocampal regions when challenged with prolonged pain (Nascimento et al., 2019). The latter region has an integral role in episodic memory and emotional pain processing. In addition, COMT rs6267 GT genotype was associated with depression and Parkinson's disease pain (Lin et al., 2017). Another COMT variant that has been associated with cognition is rs4818, where the wild type CC genotype has also been shown to have lower efficiency at processing emotionally arousing stimuli (Roussos, Giakoumaki, Pavlakis, Bitsios, 2008). 
This may predispose carriers to stress and dysfunctional responses in the face of disadvantageous situations such as chronic pain. The collective data is therefore suggesting that sequence variations within the COMT gene may reduce opioid mediated inhibitory control of pain, impact brain activity in cognitive domains and hence alter both the physiological and psychological domains of pain processing in a chronic pain condition. Chronic tendon pain affects mood and general affect in sufferers (Mkumbuzi et al., 2020), as well as being associated with altered conditioned pain modulation (Tompra et al., 2016) which is a proxy for the internal analgesic system. Since the internal analgesic system and mood are both reliant on COMT, any aberrations in COMT are relevant to the study of chronic tendon pain.

\section{Conclusion}

In conclusion, the causes of pain in tendinopathy are still unknown. As genetic variation is implicated in a variety of other pain conditions, a plausible extension of this work would be to explore the genetics of the main symptom in tendinopathy, pain, to further characterise its underlying mechanisms. Some of the genes that have previously been implicated in the pain associated with other conditions are also of interest in tendinopathy as they encode components of the tendon ECM, ion channels, inflammatory mediators and the internal analgesic system (Table 1). This review is by no means exhaustive; however, it does provide a theoretical framework on which to test the hypothesis that genetic variations previously associated with other pain conditions could, at least in part, modulate the variability observed in the pain syndrome of chronic tendinopathy. Using available and emerging technologies will allow us to identify the various genes that are implicated in tendon pain and this, in turn, allows us to explore the possible biological mechanisms underlying tendon pain. Hence, studying the genetic contribution of tendon pain may help identify the mechanisms involved in tendon pain as well as provide new therapeutic targets or strategies.

\section{References}

Abate, M., Silbernagel, K.G., Siljeholm, C., Di Iorio, A., De Amicis, D., Salini, V., Werner, S., Paganelli, R. (2009). Pathogenesis of tendinopathies: inflammation or degeneration? Arthritis Research \& Therapy, 11 (3), 235. DOI: 10.1186/ar2723.

Abrahams, Y., Laguette, M.J., Prince, S., Collins, M. (2013). Polymorphisms within the COL5A1 3???-UTR That Alters mRNA Structure and the MIR608 Gene are Associated with Achilles Tendinopathy. Annals of Human Genetics, 77 (3), 204-214. DOI: 10.1111/ ahg.12013.

Alakhdar Mohmara, Y., Cook, J., Bemtez-Martmez, J.C., McPeek, E.R., Aguilar, A.A., Olivas, E.S., Hernandez-Sanchez, S. (2020). Influence of genetic factors in elbow tendon pathology: a case-control study. Scientific Reports, 10 (1), 1-8. DOI: 10.1038/ s41598-020-63030-7.

Applebaum, E., Nackley, A.G., Bair, E., Maixner, W., Khan, A.A. (2015). Genetic Variants in Cyclooxygenase-2 Contribute to Posttreatment Pain among Endodontic Patients. Journal of Endodontics, 41 (8), 1214-1218. DOI: 10.1016/j.joen.2015.04.021.

Avcin, T., Makitie, O., Susic, M., Miller, S., Thorne, C., Tenenbaum, J., Laxer, R.M., Cole, WG. (2008). Early-onset osteoarthritis due to otospondylomegaepiphyseal dysplasia in a family with a novel splicing mutation of the COL11A2 gene. Journal of Rheumatology, 35 (5), 920-926.

Azimzadeh, P., Khorram Khorshid, H.R., Akhondi, M.M., Shirazi, A. (2016). Association of interleukin-16 polymorphisms with disease progression and susceptibility in endometriosis. International Journal of Immunogenetics, 43 (5), 297-302. DOI: 10.1111/iji.12281.

Bakkegaard, M., Johannsen, F.E., Højgaard, B., Langberg, H. (2015). Ultrasonography as a prognostic and objective parameter in Achilles tendinopathy: A prospective observational study. European Journal of Radiology, 84 (3), 458-462. DOI: 10.1016/j. ejrad.2014.11.028. 
Bali, K.K., Hackenberg, M., Lubin, A., Kuner, R., Devor, M. (2014). Sources of individual variability: MiRNAs that predispose to neuropathic pain identified using genome-wide sequencing. Molecular Pain, 10 (1), 1-15. DOI: 10.1186/1744-8069-10-22.

Barbosa, F.R., Matsuda, J.B., Mazucato, M., De Castro Franęa, S., Zingaretti, S.M., Da Silva, L.M., Martinez-Rossi, N.M., Junior, M.F., Marins, M., Fachin, A.L. (2012). Influence of catechol-O-methyltransferase (COMT) gene polymorphisms in pain sensibility of Brazilian fibromialgia patients. Rheumatology International, 32 (2), 427-430. DOI: 10.1007/s00296- 010-1659-z.

Battery, L., Maffulli, N. (2011). Inflammation in overuse tendon injuries. Sports Medicine and Arthroscopy Review, 19 (3), 213-217. DOI: 10.1097/JSA.0b013e31820e6a92.

Baumbauer, K.M., Ramesh, D., Perry, M., Carney, K.B., Julian, T., Glidden, N., Dorsey, S.G., Starkweather, A.R., Young, E.E. (2020). Contribution of COMT and BDNF Genotype and Expression to the Risk of Transition from Acute to Chronic Low Back Pain. Clinical Journal of Pain, 36 (6), 430-439. DOI: 10.1097/AJP.0000000000000819.

Berta, T., Lee, J.E., Park, C.-K. (2017). Unconventional role of caspase-6 in spinal microglia activation and chronic pain: Invited review for Mediators of Inflammation. Microglia in Health and Disease: A Double-Edge Sword, Special Issue, 2017, 1-8. DOI: $10.1155 / 2017 / 9383184$.

Bessler, H., Shavit, Y., Mayburd, E., Smirnov, G., Beilin, B. (2006). Postoperative pain, morphine consumption, and genetic polymorphism of IL-ip and IL-1 receptor antagonist. Neuroscience Letters, 404 (1-2), 154-158. DOI: 10.1016/j.neulet.2006.05.030.

Białecka, M., Jurewicz, A., Machoy-Mokrzyńska, A., Kurzawski, M., Leźnicka, K., Dziedziejko, V., Safranow, K., Droździk, M., Bohatyrewicz, A. (2016). Effect of interleukin 6-174G>C gene polymorphism on opioid requirements after total hip replacement. Journal of Anesthesia, 30 (4), 562-567. DOI: 10.1007/s00540-016-2167-4.

Bjersing, J.L., Bokarewa, M.I., Mannerkorpi, K. (2015). Profile of circulating microRNAs in fibromyalgia and their relation to symptom severity: an exploratory study. Rheumatology International, 35 (4), 635-642. DOI: 10.1007/s00296-014-3139-3.

Bjorland, S., Moen, A., Schistad, E., Gjerstad, J., Røe, C. (2016). Genes associated with persistent lumbar radicular pain; a systematic review. BMC Musculoskeletal Disorders, 17 (1), 1-10. DOI: 10.1186/s12891-016-1356-5.

Blesneac, I., Themistocleous, A.C., Fratter, C., Conrad, L.J., Ramirez, J D., Cox, J.J., Tesfaye, S., Shillo, P.R., Rice, A.S.C., Tucker, S.J., Bennett, D.L.H. (2018). Rare NaV1.7 variants associated with painful diabetic peripheral neuropathy. Pain, 159 (3), $469-480$. DOI: 10.1097/j.pain.0000000000001116.

Boadas-Vaello, P., Homs, J., Reina, F., Carrera, A., Verdu, E. (2017). Neuroplasticity of Supraspinal Structures Associated with Pathological Pain. Anatomical Record, 300 (8), 1481-1501. DOI: 10.1002/ar.23587.

Bortsov, A.V., Devor, M., Kaunisto, M.A., Kalso, E., Brufsky, A., Kehlet, H., Aasvang, E., Bittner, R., Diatchenko, L., Belfer, I. (2019). CACNG2 polymorphisms associate with chronic pain after mastectomy. Pain, 160 (3), 561-568. DOI: 10.1097/j. pain. 0000000000001432 .

Brenton, A., Lee, C., Kabaria, S., Hafez, M., Kantorovich, S., Meshkin, B. (2017). (402) Association of Catechol-O-Methyltransferase Single Nucleotide Polymorphisms, Ethnicity, and Sex in a Large Cohort of Fibromyalgia Patients. The Journal of Pain, 18 (4), S75. DOI: 10.1016/j.jpain.2017.02.252.

Burger, M.C., de Wet, H., Collins, M. (2015). Interleukin and growth factor gene variants and risk of carpal tunnel syndrome. Gene, 564 (1), 67-72. DOI: 10.1016/j.gene.2015.03.047.

Caneiro, J.P., Roos, E.M., Barton, C.J., O'Sullivan, K., Kent, P., Lin, I., Choong, P., Crossley, KM., Hartvigsen, J., Smith, A.J., O'Sullivan, P. (2020). It is time to move beyond a $€$ body region silos' to manage musculoskeletal pain: Five actions to change clinical practice. British Journal of Sports Medicine, 54 (8), 438-439. DOI: 10.1136/bjsports-2018-100488.

Chidambaran, V., Gang, Y., Pilipenko, V., Ashton, M., Ding, L. (2019). Systematic Review and Meta-Analysis of Genetic Risk of Developing Chronic Postsurgical Pain. Journal of Pain, 00 (00). DOI: 10.1016/j.jpain.2019.05.008.

Ciszek, B.P., Khan, A.A., Dang, H., Slade, G.D., Smith, S., Bair, E., Maixner, W., Zolnoun, D., Nackley, A.G. (2015). MicroRNA expression profiles differentiate chronic pain condition subtypes. Translational Research, 166 (6), 706-720.e11. DOI: 10.1016/j. trsl.2015.06.008.

Cook, J.L., Purdam, C.R. (2009). Is tendon pathology a continuum? A pathology model to explain the clinical presentation of loadinduced tendinopathy. British Journal of Sports Medicine, 43 (6), 409-416. DOI: 10.1136/bjsm.2008.051193.

Costigan, M., Belfer, I., Griffin, R.S., Dai, F., Barrett, L.B., Coppola, G., Wu, T., Kiselycznyk, C., Poddar, M., Lu, Y., Diatchenko, L., Smith, S., Cobos, E.J., Zaykin, D., Allchorne, A., Shen, P.H., Nikolajsen, L., Karppinen, J., Männikkö, M., Kelempisioti, A., Goldman, D., Maixner, W., Geschwind, D.H., Max, M.B., Seltzer, Z., Woolf, C.J. (2010). Multiple chronic pain states are associated with a common amino acid-changing allele in KCNS1. Brain, 133 (9), 2519-2527. DOI: 10.1093/brain/awq195.

D’Addona, A., Maffulli, N., Formisano, S., Rosa, D. (2017). Inflammation in tendinopathy. Surgeon, 15 (5), 297-302. DOI: 10.1016/j. surge.2017.04.004. 
Dada, S., Burger, M.C., Massij, F., de Wet, H., Collins, M. (2016). Carpal tunnel syndrome: The role of collagen gene variants. Gene, 587 (1), 53-58. DOI: 10.1016/j.gene.2016.04.030.

Dakin, S.G., Dudhia, J., Smith, R.K.W. (2014). Resolving an inflammatory concept: The importance of inflammation and resolution in tendinopathy. Veterinary Immunology and Immunopathology, 158 (3-4), 21-127. DOI: 10.1016/j.vetimm.2014.01.007.

Dayer, C.F., Luthi, F., Le Carre, J., Vuistiner, P., Terrier, P., Benaim, C., Giacobino, J.P., Leger, B. (2019). Differences in the miRNA signatures of chronic musculoskeletal pain patients from neuropathic or nociceptive origins. PLOS ONE, 14 (7), 1-21. DOI: 10.1371/journal.pone.0219311.

Dean, B.J.F., Snelling, S.J.B., Dakin, S.G., Murphy, R.J., Javaid, M.K., Carr, A. J. (2015). Differences in glutamate receptors and inflammatory cell numbers are associated with the resolution of pain in human rotator cuff tendinopathy. Arthritis Research and Therapy, 17 (1), 1-10. DOI: 10.1186/s13075-015-0691-5.

Diatchenko, L., Slade, G.D., Nackley, A.G., Bhalang, K., Sigurdsson, A., Belfer, I., Goldman, D., Xu, K., Shabalina, S.A., Shagin, D., Max, M.B., Makarov, S.S., Maixner, W. (2005). Genetic basis for individual variations in pain perception and the development of a chronic pain condition. Human Molecular Genetics, 14 (1), 135-143. DOI: 10.1093/hmg/ddi013.

Diniz-Fernandes, T., Godoy-Santos, A.L., Santos, M.C., Pontin, P., Pereira, C.A.A., Jardim, Y.J., Velosa, A.P.P., Maffulli, N., Teodoro, W.R., Capelozzi, V.L. (2018). Matrix metalloproteinase-1 (MMP-1) and (MMP-8) gene polymorphisms promote increase and remodeling of the collagen iii and $v$ in posterior tibial tendinopathy. Histology and Histopathology, 33 (9), 929-936. DOI: 10.14670/ HH-11-982.

Docking, S.I., Ooi, C.C., Connell, D. (2015). Tendinopathy: Is imaging telling us the entire story? Journal of Orthopaedic and Sports Physical Therapy, 45 (11), 842-852. DOI: 10.2519/jospt.2015.5880.

Duan, G., Xiang, G., Guo, S., Zhang, Y., Ying, Y., Huang, P., Zheng, H., Zhang, M., Li, N., Zhang, X. (2016). Genotypic Analysis of SCN9A for Prediction of Postoperative Pain in Female Patients Undergoing Gynecological Laparoscopic Surgery. Pain Physician, 19, E151-162.

Dussor, G. (2015). ASICs as therapeutic targets for migraine. Neuropharmacology, 94, 64-71. DOI: 10.1016/j.neuropharm.2014.12.015.

Egan, M.F., Goldberg, T.E., Kolachana, B.S., Callicott, J.H., Mazzanti, C.M., Straub, R.E., Goldman, D., Weinberger, D.R. (2001). Effect of COMT Val108/158 Met genotype on frontal lobe function and risk for schizophrenia. Proceedings of the National Academy of Sciences of the United States of America, 98 (12), 6917-6922. DOI: 10.1073/pnas.111134598.

El Khoury, L., Ribbans, W.J., Raleigh, SM. (2016). MMP3 and TIMP2 gene variants as predisposing factors for Achilles tendon pathologies: Attempted replication study in a British case-control cohort. Meta Gene, 9, 52-55. DOI: 10.1016/j.mgene.2016.03.007.

Elramah, S., Landry, M., Favereaux, A. (2014). MicroRNAs regulate neuronal plasticity and are involved in pain mechanisms. Frontiers in Cellular Neuroscience, 8 (FEB), 1-15. DOI: 10.3389/fncel.2014.00031.

Estacion, M., Harty, T.P., Choi, J.S., Tyrrell, L., Dib-Hajj, S.D., Waxman, S.G. (2009). A sodium channel gene SCN9A polymorphism that increases nociceptor excitability. Annals of Neurology, 66 (6), 862-866. DOI: 10.1002/ana.21895.

Femandez-De-Las-Penas, C., Ambite-Quesada, S., Palacios-Cena, M., Guillem-Mesado, A., Guerrero-Peral, A., Pareja, J.A., ArendtNielsen, L. (2019). Catechol-O-Methyltransferase (COMT) rs4680 Val158Met Polymorphism is Associated With Widespread Pressure Pain Sensitivity and Depression in Women With Chronic, but not Episodic, Tension-Type Headache. Clinical Journal of Pain, 35 (4), 345-352. DOI: 10.1097/AJP.0000000000000684.

Fillingim, R.B., Wallace, M.R., Herbstman, D.M., Ribeiro-Dasilva, M., Staud, R. (2008). Genetic contributions to pain: A review of findings in humans, Oral Diseases, 14 (8), 673-682.DOI: 10.1111/j.1601-0825.2008.01458.x.

Foulkes, T., Wood, J.N. (2008). Pain genes. PLoS Genetics, 4 (7), 1-9. DOI: 10.1371/journal.pgen.1000086.

Gammaitoni, A.R., Goitz, H.T., Marsh, S., Marriott, T B., Galer, B.S. (2013). Heated lidocaine/tetracaine patch for treatment of patellar tendinopathy pain. Journal of Pain Research, 6, 565-570. DOI: 10.2147/JPR.S46239.

Gan, X.-L., Lin, Y.-H., Zhang, Y., Yu, T.-H., Hu, L.-N. (2010). Association of an Interleukin-16 Gene Polymorphism with the Risk and Pain Phenotype of Endometriosis. DNA and Cell Biology, 29 (11), 663-667. DOI: 10.1089/dna.2010.1049.

Govil, M., Mukhopadhyay, N., Holwerda, T., Sluka, K., Rakel, B., Schutte, D.L. (2020). Effects of genotype on TENS effectiveness in controlling knee pain in persons with mild to moderate osteoarthritis. European Journal of Pain (United Kingdom), 24 (2), 398-412. DOI: 10.1002/ejp.1497.

Guo, T.M., Liu, M., Zhang, Y.G., Guo, W.T., Wu, S.X. (2011). Association between caspase-9 promoter region polymorphisms and discogenic low back pain. Connective Tissue Research, 52 (2), 133-138. DOI: 10.3109/03008207.2010.487621.

Hagen, K., Pettersen, E., Stovner, L.J., Skorpen, F., Zwart, J. (2006). Val158Met polymorphism in the Catechol-O-methyltransferase. BMC Musculoskeletal Disorders, 5, 4-8. DOI: 10.1186/1471-2474-7-40. 
Hay, M., Patricios, J., Collins, R., Branfield, A., Cook, J., Handley, C.J., September, A.V., Posthumus, M., Collins, M. (2013). Association of type XI collagen genes with chronic Achilles tendinopathy in independent populations from South Africa and Australia. British Journal of Sports Medicine, 47 (9), 569-574. DOI: 10.1136/bjsports-2013-092379.

Ho, K.W.D., Wallace, M.R., Sibille, K.T., Bartley, E.J., Cruz-Almeida, Y., Glover, T.L., King, C.D., Goodin, B.R., Addison, A., Edberg, J.C., Staud, R., Bradley, L.A., Fillingim, R.B. (2017). Single Nucleotide Polymorphism in the COL11A2 Gene Associated with Heat Pain Sensitivity in Knee Osteoarthritis. Molecular Pain, 13, 1-11. DOI: 10.1177/1744806917724259.

Hoeijmakers, J., Merkies, I., Gerrits, M., Waxman, S., Faber, C. (2012). Genetic aspects of sodium channelopathy in small fiber neuropathy. Clinical Genetics, 82 (4), 351-358. DOI: 10.1111/j.1399-0004.2012.01937.x.

Holliday, K.L., Thomson, W., Neogi, T., Felson, D.T., Wang, K., Wu, F.C., Huhtaniemi, I.T., Bartfai, G., Casanueva, F., Forti, G., Kula, K., Punab, M., Vanderschueren, D., Macfarlane, G.J., Horan, M.A., Ollier, W., Payton, A., Pendleton, N., McBeth, J. (2012). The nonsynonymous SNP, R1150W, in SCN9A is not associated with chronic widespread pain susceptibility. Molecular Pain, 8 (1), 1. DOI: 10.1186/1744-8069-8-72.

Hooten, W.M., Hu, D., Cunningham, J.M., lii, J.L.B. (2019). Effect of catechol-O-methyltransferase on opioid-induced hyperalgesia in adults with chronic pain. DOI: 10.1177/1744806919848929.

Huang, J., Yang, Y., Zhao, P., Gerrits, M.M., Hoeijmakers, J.G.J., Bekelaar, K., Merkies, I.S.J., Faber, C.G., Dib-Hajj, S.D., Waxman, S.G. (2013). Small-Fiber Neuropathy Nav1.8 Mutation Shifts Activation to Hyperpolarized Potentials and Increases Excitability of Dorsal Root Ganglion Neurons. Journal of Neuroscience, 33 (35), 14087-14097. DOI: 10.1523/JNEUROSCI.2710-13.2013.

Jacobsen, L.M., Schistad, E.I., Storesund, A., Pedersen, L.M., Espeland, A., Rygh, L.J., R0e, C., Gjerstad, J. (2013). The MMP1 rs1799750 $2 \mathrm{G}$ allele is associated with increased low back pain, sciatica, and disability after lumbar disk herniation. Clinical Journal of Pain, 29 (11), 967-971. DOI: 10.1097/AJP.0b013e31827df7fd.

Ji, R.R., Gereau IV, R.W., Malcangio, M., Strichartz, G.R. (2009). MAP kinase and pain. Brain Research Reviews, 60 (1), 135-148. DOI: 10.1016/j.brainresrev.2008.12.011.

Joseph, E.K., Levine, J.D. (2004). Caspase signalling in neuropathic and inflammatory pain in the rat. European Journal of Neuroscience, 20 (11), 2896-2902. DOI: 10.1111/j.1460-9568.2004.03750.x.

Kambur, O., Kaunisto, M.A., Tikkanen, E., Leal, S.M., Ripatti, S., Kalso, E.A. (2013). Effect of catechol-o-methyltransferase-gene (COMT) variants on experimental and acute postoperative pain in 1,000 women undergoing surgery for breast cancer. Anesthesiology, 119 (6), 1422-1433. DOI: 10.1097/aln.0000000000000013.

Kang, X., Tian, B., Zhang, L., Ge, Z., Zhao, Y., Zhang, Y. (2019). Relationship of common variants in MPP7, TIMP2 and CASP8 genes with the risk of chronic achilles tendinopathy. Scientific Reports, 9 (1), 1-6. DOI: 10.1038/s41598-019-54097-y.

Khoury, L. El, Posthumus, M., Collins, M., Van Der Merwe, W., Handley, C., Cook, J., Raleigh, S.M. (2015). ELN and FBN2 gene variants as risk factors for two sports-related musculoskeletal injuries. International Journal of Sports Medicine, 36 (4), 333-337. DOI: 10.1055/s-0034-1390492.

Knisely, M.R., Conley, Y.P., Kober, K.M., Smoot, B., Paul, S.M., Levine, J.D., Miaskowski, C. (2018). Associations Between Catecholaminergic and Serotonergic Genes and Persistent Breast Pain Phenotypes After Breast Cancer Surgery. Journal of Pain, 19 (10), 1130-1146. DOI: 10.1016/j.jpain.2018.04.007.

Kolesnikov, Y., Gabovits, B., Levin, A., Veske, A., Qin, L., Dai, F., Belfer, I. (2013). Chronic pain after lower abdominal surgery: Do catecholO-methyl transferase/opioid receptor p-1 polymorphisms contribute? Molecular Pain, 9 (1), 1. DOI: 10.1186/1744-8069-9-19.

Kozlovskaia, M., Vlahovich, N., Ashton, K.J., Hughes, D.C. (2017). Biomedical Risk Factors of Achilles Tendinopathy in Physically Active People: a Systematic Review. Sports Medicine - Open, 3 (1), 1-14. DOI: 10.1186/s40798-017-0087-y.

Kular, L., Rivat, C., Lelongt, B., Calmel, C., Laurent, M., Pohl, M., Kitabgi, P., Melik-Parsadaniantz, S., Martinerie, C. (2012). NOV/CCN3 attenuates inflammatory pain through regulation of matrix metalloproteinases-2 and -9. Journal of Neuroinflammation, 9, 1-20. DOI: 10.1186/1742-2094-9-36.

Lagas, I.F., Fokkema, T., Verhaar, J.A.N., Bierma-Zeinstra, S.M.A., van Middelkoop, M., de Vos, R.J. (2020). Incidence of Achilles tendinopathy and associated risk factors in recreational runners: A large prospective cohort study. Journal of Science and Medicine in Sport, 23 (5), 448-452. DOI: 10.1016/j.jsams.2019.12.013.

Lapvetelainen, T., Hyttinen, M.M., Saamanen, A.M., Langsjo, T., Sahlman, J., Felszeghy, S., Vuorio, E., Helminen, H.J. (2002). Lifelong voluntary joint loading increases osteoarthritis in mice housing a deletion mutation in type II procollagen gene, and also in nontransgenic mice. Annals of the Rheumatic Diseases, 61 (9), 810-817. DOI: 10.1136/ard.61.9.810.

Lee, P.J., Delaney, P., Keogh, J., Sleeman, D., Shorten, G.D. (2011). Catecholamine-O-Methyltransferase Polymorphisms. 27 (2), 93-101. 
Leinders, M., Uęeyler, N., Thomann, A., Sommer, C. (2017). Aberrant microRNA expression in patients with painful peripheral neuropathies. Journal of the Neurological Sciences, 380, 242-249. DOI: 10.1016/j.jns.2017.07.041.

Li, J., Xu, L., Deng, X., Jiang, C., Pan, C., Chen, L., Han, Y., Dai, W., Hu, L., Zhang, G., Cheng, Z., Liu, W. (2016). N-acetylcysteine attenuates neuropathic pain by suppressing matrix metalloproteinases. Pain, 157 (8), 1711-1723. DOI: 10.1097/j. pain.0000000000000575.

Li, W., Chen, Y., Yin, B., Zhang, L. (2014). Pain in parkinson's disease associated with COMT gene polymorphisms. Behavioural Neurology. DOI: 10.1155/2014/304203.

Lian, Ø., Dahl, J., Ackermann, P.W., Frihagen, F., Engebretsen, L., Bahr, R. (2006). Pronociceptive and antinociceptive neuromediators in patellar tendinopathy. American Journal of Sports Medicine, 34 (11), 1801-1808. DOI: 10.1177/0363546506289169.

Lin, C.-H., Chaudhuri, K.R., Fan, J.-Y., Ko, C.-I., Rizos, A., Chang, C.-W., Lin, H.-I., Wu, Y.-R. (2017). Depression and Catechol-Omethyltransferase (COMT) genetic variants are associated with pain in Parkinson's disease. Scientific Reports, 7 (1), 6306. DOI: 10.1038/s41598-017-06782-z.

Linnstaedt, S.D., Walker, M.G., Parker, J.S., Yeh, E., Sons, R.L., Zimny, E., Lewandowski, C., Hendry, P.L., Damiron, K., Pearson, C., Velilla, M.A., O'Neil, B. J., Jones, J., Swor, R., Domeier, R., Hammond, S., McLean, S.A. (2015). MicroRNA circulating in the early aftermath of motor vehicle collision predict persistent pain development and suggest a role for microRNA in sex-specific pain differences. Molecular Pain, 11 (1), 1-11. DOI: 10.1186/s12990- 015-0069-3.

Martmez-Jauand, M., Sitges, C., Rodriguez, V., Picornell, A., Ramon, M., Buskila, D., Montoya, P. (2013). Pain sensitivity in fibromyalgia is associated with catechol-O- methyltransferase (COMT) gene. European Journal of Pain (United Kingdom), 17 (1), 16-27. DOI: 10.1002/j.1532-2149.2012.00153.x.

Martire, L.M., Wilson, S.J., Small, B.J., Conley, Y.P., Janicki, P.K., Sliwinski, M.J. (2016). COMT and OPRM1 genotype associations with daily knee pain variability and activity induced pain. Scandinavian Journal of Pain, 10, 6-12. DOI: 10.1016/j.sjpain.2015.07.004.

Mc Auliffe, S., Synott, A., Casey, H., Mc Creesh, K., Purtill, H., O'Sullivan, K. (2017). Beyond the tendon: Experiences and perceptions of people with persistent Achilles tendinopathy. Musculoskeletal Science and Practice, 29, 108-114. DOI: 10.1016/j. msksp.2017.03.009.

McCann, B., Miaskowski, C., Koetters, T., Baggott, C., West, C., Levine, J.D., Elboim, C., Abrams, G., Hamolsky, D., Dunn, L., Rugo, H., Dodd, M., Paul, S.M., Cooper, J., Cooper, B., Schmidt, B., Langford, D., Cataldo, J., Aouizerat, B.E. (2012). Associations between pro- and anti-inflammatory cytokine genes and breast pain in women prior to breast cancer surgery. Journal of Pain, 13 (5), 425-437. DOI: 10.1016/j.jpain.2011.02.358.

Millan, M.J. (1999). The induction of pain: An integrative review. Progress in Neurobiology, 57 (1), 1-164. DOI: 10.1016/ S0301-0082(98)00048-3.

Miranpuri, G.S., Schomberg, D.T., Alrfaei, B., King, K.C., Rynearson, B., Wesley, V.S., Khan, N., Obiakor, K., Wesley, U.V., Resnick, D.K. (2016). Role of matrix metalloproteinases 2 in spinal cord injury-induced neuropathic pain. Annals of Neurosciences, 23 (1), 25-32. DOI: 10.1159/000443553.

Mkumbuzi, N.S., September, A.V., Posthumus, M., Oulo, B., Mafu, T.S., Collins, M. (2020). Characterisation of Achilles tendon pain in recreational runners using multidimensional pain scales. Journal of Science and Medicine in Sport, 23 (3), 258-263. DOI: 10.1016/j.jsams.2019.10.016.

Mladenovic, I., Krunic, J., Supic, G., Kozomara, R., Bokonjic, D., Stojanovic, N., Magic, Z. (2018). Pulp Sensitivity: Influence of Sex, Psychosocial Variables, COMT Gene, and Chronic Facial Pain. Journal of Endodontics, 44 (5), 717-721.e1. DOI: 10.1016/j. joen.2018.02.002.

Moen, A., Schistad, E.I., Rygh, L.J., Re, C., Gjerstad, J. (2014). Role of IL1A rs1800587, IL1B rs1143627 and IL1RN rs2234677 genotype regarding development of chronic lumbar radicular pain; A prospective one-year study. PLOS ONE, 9 (9), 1-5. DOI: 10.1371/ journal.pone.0107301.

Mousavizadeh, R., Khosravi, S., Behzad, H., McCormack, R.G., Duronio, V., Scott, A. (2014). Cyclic strain alters the expression and release of angiogenic factors by human tendon cells. PLOS ONE, 9 (5). DOI: 10.1371/journal.pone.0097356.

Mu, J., Ge, W., Zuo, X., Chen, Y., Huang, C. (2013). Analysis of association between IL-1^ ${ }^{\wedge}$, CASP-9, and GDF5 variants and low-back pain in Chinese male soldiers. J Neurosurg Spine, 19, 243-247.

Nascimento, T.D., Yang, N., Salman, D., Jassar, H., Kaciroti, N., Bellile, E., Danciu, T., Koeppe, R., Stohler, C., Zubieta, J.K., Ellingrod, V., DaSilva, A.F. (2019). p-Opioid Activity in Chronić TMD Pain Is Associated with COMT Polymorphism. Journal of Dental Research, 98 (12), 1324-1331. DOI: 10.1177/0022034519871938.

Neely, G.G., Hess, A., Costigan, M., Keene, A.C., Goulas, S., Langeslag, M., Griffin, R.S., Belfer, I., Dai, F., Smith, S.B., Diatchenko, L., Gupta, V., Xia, C-P., Amann, S., Kreitz, S., Heindl-Erdmann, C., Wolz, S., Ly, C.V., Arora, S., Sarangi, R., Dan, D., Novatchkova, M., 
Rosenzweig, M., Gibson, D.G., Truong, D., Schramek, D., Zoranovic, T., Cronin, S.J.F., Angjeli, B., Brune, K., Dietzl, G., Maixner, W., Meixner, A., Thomas, W., Pospisilik, J.A., Alenius, M., Kress, M., Subramaniam, S., Garrity, P.A., Bellen, H.J., Woolf, C.J., Penninger, J.M. (2010). A genome-wide Drosophila screen for heat nociception identifies a2 23 as an evolutionarily conserved pain gene. NIH Public Access, 143 (4), 628-638. DOI: 10.1016/j.cell.2010.09.047.

Nell, E.M., Van Der Merwe, L., Cook, J., Handley, C.J., Collins, M., September, A.V. (2012). The apoptosis pathway and the genetic predisposition to Achilles tendinopathy. Journal of Orthopaedic Research, 30 (11), 1719-1724. DOI: 10.1002/jor.22144.

Nicholl, B.I., Holliday, K.L., Macfarlane, G.J., Thomson, W., Davies, K.A., O’Neill, T.W., Bartfai, G., Boonen, S., Casanueva, F., Finn, J.D., Forti, G., Giwercman, A., Huhtaniemi, I.T., Kula, K., Punab, M., Silman, A.J., Vanderschueren, D., Wu, F.C. W., McBeth, J., Jiang, M. (2010). No evidence for a role of the catechol-O-methyltransferase pain sensitivity haplotypes in chronic widespread pain. Annals of the Rheumatic Diseases, 69 (11), 2009-2012. DOI: 10.1136/ard.2009.126086.

Olesen, A.E., Nielsen, L M., Feddersen, S., Erlenwein, J., Petzke, F., Przemeck, M., Christrup, L.L., Drewes, A.M. (2018). Association Between Genetic Polymorphisms and Pain Sensitivity in Patients with Hip Osteoarthritis. Pain Practice, 18 (5), 587-596. DOI: 10.1111/papr.12648.

Omair, A., Mannion, A.F., Holden, M., Fairbank, J., Lie, B.A., Hagg, O., Fritzell, P., Brox, J.I. (2015). Catechol-O-methyltransferase (COMT) gene polymorphisms are associated with baseline disability but not long-term treatment outcome in patients with chronic low back pain. European Spine Journal, 24 (11), 2425-2431. DOI: 10.1007/s00586-015-3866-5.

Orlova, I.A., Alexander, G.M., Qureshi, R.A., Sacan, A., Graziano, A., Barrett, J.E., Schwartzman, R.J., Ajit, S.K. (2011). MicroRNA modulation in complex regional pain syndrome. Journal of Translational Medicine, 9 (1), 195. DOI: 10.1186/1479-5876-9-195.

Owens, B.D., Wolf, J.M., Seelig, A.D., Jacobson, I.G., Boyko, E.J., Smith, B., Ryan, M.A.K., Gackstetter, G.D., Smith, T.C. (2013). Risk factors for lower extremity tendinopathies in military personnel. Orthopaedic Journal of Sports Medicine, 1 (1), 1-8. DOI: $10.1177 / 2325967113492707$.

Packiasabapathy, S., Horn, N., Sadhasivam, S. (2019). HHS Public Access. 31 (6), 749-755. DOI: 10.1097/AC0.0000000000000660.

Park, D.J., Kim, S.H., Nah, S.S., Lee, J.H., Kim, S.K., Lee, Y.A., Hong, S.J., Kim, H.S., Lee, H.S., Kim, H.A., Joung, C.I., Kim, S.H., Lee, S.S. (2016). Association between catechol-O-methyl transferase gene polymorphisms and fibromyalgia in a Korean population: A case-control study. European Journal of Pain (United Kingdom), 20 (7), 1131-1139. DOI: 10.1002/ejp.837.

Patanwala, I.Y., Lamvu, G., Ledger, W.J., Witzeman, K., Marvel, R., Rapkin, A., Bongiovanni, A.M., Feranec, J., Witkin, S.S. (2017). Catechol-O- methyltransferase gene polymorphism and vulvar pain in women with vulvodynia. American Journal of Obstetrics and Gynecology, 216 (4), 395.e1-395.e6. DOI: 10.1016/j.ajog.2016.10.020.

Peters, M.J., Broer, L., Willemen, H.L.D.M., Eiriksdottir, G., Hocking, L.J., Holliday, K.L., Horan, M.A., Meulenbelt, I., Neogi, T., Popham, M., Schmidt, C.O., Soni, A., Valdes, A.M., Amin, N., Dennison, E.M., Eijkelkamp, N., Harris, T.B., Hart, D.J., Hofman, A., Huygen, F.J., Jameson, K.A., Jones, G.T., Laune, L.J., Kerkhof, H.J., de Kruijf, M., McBeth, J., Kloppenburg, M., Ollie, W.E., Oostra, B., Payton, A., Rivadeneira, F., Smith, B.H., Smith, A.V., Stolk, L., Teumer, A., Thomson, W., Uitterlinden, A.G., Wang, K., van Wingerden, S.H., Arden, N.K., Cooper, C., Felson, D., Gudnason, V., Macfarlane, G.J., Pendleton, N., Slagboom, P.E., Spector, T.D., Völzke, H., Kavelaars, A., van Duijn, C.M., Williams, F.M., Van Meurs, J.B.J. (2013). Genome-wide association study meta-analysis of chronic widespread pain: Evidence for involvement of the 5 p15.2 region. Annals of the Rheumatic Diseases, 72 (3), 427-436. DOI: 10.1136/annrheumdis-2012-201742.

Planello, A.C., Campos, M.I.G., Meloto, C.B., Secolin, R., Rizatti-Barbosa, C.M., Line, S.R.P., De Souza, A.P. (2011). Association of matrix metalloproteinase gene polymorphism with temporomandibular joint degeneration. European Journal of Oral Sciences, 119 (1), 1-6. DOI: 10.1111/j.1600-0722.2010.00803.x.

Plinsinga, M.L., Brink, M.S., Vicenzino, B., van Wilgen, C.P. (2015). Evidence of Nervous System Sensitization in Commonly Presenting and Persistent Painful Tendinopathies: A Systematic Review. Journal of Orthopaedic \& Sports Physical Therapy, 45 (11), $864-$ 875. DOI: 10.2519/jospt.2015.5895.

Rahim, M., Gibbon, A., Collins, M., September, A.V. (2019). Genetics of musculoskeletal soft tissue injuries: Current status, challenges, and future directions. Sports, Exercise, and Nutritional Genomics: Current Status and Future Directions, 317-339. DOI: 10.1016/ B978-0-12-816193- 7.00015-4.

Raine, E.V.A., Dodd, A.W., Reynard, L.N., Loughlin, J. (2013). Allelic expression analysis of the osteoarthritis susceptibility gene COL11A1 in human joint tissues. BMC Musculoskeletal Disorders, 14 (1), 1.DOI: 10.1186/1471-2474-14-85.

Reimann, F., Cox, J.J., Belfer, I., Diatchenko, L., Zaykin, D.V, McHale, D.P., Drenth, J.P.H., Dai, F., Wheeler, J., Sanders, F., Wood, L., Wu, T.-X., Karppinen, J., Nikolajsen, L., Mannikko, M., Max, M.B., Kiselycznyk, C., Poddar, M., Te Morsche, R.H.M., ..., Woods, C.G. (2010). Pain perception is altered by a nucleotide polymorphism in SCN9A. Proceedings of the National Academy of Sciences of the United States of America, 107 (11), 5148-5153. DOI: 10.1073/pnas.0913181107. 
Reyes-Gibby, C.C., Spitz, M.R., Yennurajalingam, S., Swartz, M., Jian, G., Xifeng, W., Bruera, E., Shete, S. (2009). Role of inflammation gene polymorphisms on pain severity in lung cancer patients. Cancer Epidemiology Biomarkers and Prevention, 18 (10), $2636-$ 2642. DOI: 10.1158/1055- 9965.EPI-09-0426.

Richardson, S.M., Doyle, P., Minogue, B.M., Gnanalingham, K., Hoyland, J.A. (2009). Increased expression of matrix metalloproteinase-10, nerve growth factor and substance $P$ in the painful degenerate intervertebral disc. Arthritis Research and Therapy, 11 (4), 1-8. DOI: 10.1186/ar2793.

Rio, E., Moseley, L., Purdam, C., Samiric, T., Kidgell, D., Pearce, A.J., Jaberzadeh, S., Cook, J. (2014). The pain of tendinopathy: Physiological or pathophysiological? In Sports Medicine, 44 (1), 9-23. DOI: 10.1007/s40279-013-0096-z.

Roussos, P., Giakoumaki, S.G., Pavlakis, S., Bitsios, P. (2008). Planning, decision-making and the COMT rs4818 polymorphism in healthy males. Neuropsychologia, 46 (2), 757-763. DOI: 10.1016/j.neuropsychologia.2007.10.009.

Ruau, D., Dudley, J.T., Chen, R., Phillips, N.G., Swan, G.E., Lazzeroni, L.C., Clark, J.D., Butte, A.J., Angst, M.S. (2012). Integrative approach to pain genetics identifies pain sensitivity loci across diseases. PLoS Computational Biology, 8 (6). DOI: 10.1371/ journal.pcbi.1002538.

Rydman, E., Comasco, E., Pettersson, H., Oreland, L., Ponzer, S., Ottosson, C. (2017). COMT genotype and non-recovery after a whiplash injury in a Northern European population. BMC Musculoskeletal Disorders, 18 (1), 4-10. DOI: 10.1186/s12891-017-1810-z.

Sadhasivam, S., Chidambaran, V., Olbrecht, V.A., Esslinger, H.R., Zhang, K., Zhang, X., Martin, L.J. (2014). Genetics of pain perception, COMT and postoperative pain management in children. Pharmacogenomics, 15 (3), 277-284. DOI: 10.2217/pgs.13.248.

Sanz-Rubio, D., Martin-Burriel, I., Gil, A., Cubero, P., Forner, M., Khalyfa, A., Marin, J.M. (2018). Stability of Circulating Exosomal miRNAs in Healthy Subjects article. Scientific Reports, 8 (1), 1-10. DOI: 10.1038/s41598- 018-28748-5.

Saunders, C.J., Van Der Merwe, L., Posthumus, M., Cook, J., Handley, C.J., Collins, M., September, A.V. (2013). Investigation of variants within the COL27A1 and TNC genes and Achilles tendinopathy in two populations. Journal of Orthopaedic Research, 31 (4), 632-637. DOI:10.1002/jor.22278.

Schistad, E.I., Jacobsen, L.M., R0e, C., Gjerstad, J. (2014). The interleukin- 1a gene C > T polymorphism rs1800587 is associated with increased pain intensity and decreased pressure pain thresholds in patients with lumbar radicular pain. Clinical Journal of Pain, 30 (10), 869-874. DOI: 10.1097/AJP.0000000000000048.

Schizas, N., Weiss, R., Lian, O., Frihagen, F., Bahr, R., Ackermann, P.W. (2012). Glutamate receptors in tendinopathic patients. Journal of Orthopaedic Research, 30 (9), 1447-1452. DOI: 10.1002/jor.22094.

Seale, K., Burger, M., Posthumus, M., Hager, C.K., Stattin, E., Nilsson, K.G., Collins, M., September, A.V. (2020). The Apoptosis Pathway and CASP8 Variants Conferring Risk for Acute and Overuse Musculoskeletal Injuries. Journal of Orthopaedic Research, 38 (3), 680-688. DOI: 10.1002/jor.24504.

September, A.V., Nell, E.M., O'Connell, K., Cook, J., Handley, C.J., Van Der Merwe, L., Schwellnus, M., Collins, M. (2011). A pathwaybased approach investigating the genes encoding interleukin-ip, interleukin- 6 and the interleukin-1 receptor antagonist provides new insight into the genetic susceptibility of Achilles tendinopathy. British Journal of Sports Medicine, 45 (13), 1040-1047. DOI: 10.1136/bjsm.2010.076760.

September, A.V, Cook, J., Handley, C.J., van der Merwe, L., Schwellnus, M.P., Collins, M. (2009). Variants within the COL5A1 gene are associated with Achilles tendinopathy in two populations. British Journal of Sports Medicine, 43 (5), 357-365. DOI: 10.1136/ bjsm.2008.048793.

Silbernagel, K.G., Hanlon, S., Sprague, A. (2020). Current clinical concepts: Conservative management of achilles tendinopathy. Journal of Athletic Training, 55 (5), 438-447. DOI: 10.4085/1062-6050-356-19.

Smolka, M.N., Schumann, G., Wrase, J., Grusser, S.M., Flor, H., Mann, K., Braus, D.F., Goldman, D., Buchel, C., Heinz, A. (2005). Catechol-O- methyltransferase val158met genotype affects processing of emotional stimuli in the amygdala and prefrontal cortex. Journal of Neuroscience, 25 (4), 836-842. DOI: 10.1523/JNEUROSCI.1792-04.2005.

Solovieva, S., Leino-Arjas, P., Saarela, J., Luoma, K., Raininko, R., Riihimaki, H. (2004). Possible association of interleukin 1 gene locus polymorphisms with low back pain. Pain, 109 (1-2), 8-19. DOI: 10.1016/j.pain.2003.10.020.

Stephens, K., Cooper, B.A., West, C., Paul, S.M., Baggott, C.R., Merriman, J.D., Dhruva, A., Kober, K.M., Langford, D.J., Leutwyler, H., Luce, J A., Schmidt, B.L., Abrams, G.M., Elboim, C., Hamolsky, D., Levine, J.D., Miaskowski, C., Aouizerat, B.E. (2014). Associations between cytokine gene variations and severe persistent breast pain in women following breast cancer surgery. Journal of Pain, 15 (2), 169-180. DOI: 10.1016/j.jpain.2013.09.015.

Stephens, K.E., Levine, J.D., Aouizerat, B.E., Paul, S.M., Abrams, G., Conley, Y.P., Miaskowski, C. (2017). Associations between genetic and epigenetic variations in cytokine genes and mild persistent breast pain in women following breast cancer surgery. Cytokine, 99, 203-213. DOI: 10.1016/j.cyto.2017.07.006. 
Suijkerbuijk, M.A.M., Ponzetti, M., Rahim, M., Posthumus, M. (2020). Functional polymorphisms within the inflammatory pathway regulate expression of extracellular matrix components in a genetic risk dependent model for anterior cruciate ligament injuries. Journal of Science and Medicine in Sport, 22 (11), 1219-1225. DOI: 10.1016/j.jsams.2019.07.012.

Takigawa, H., Kowa, H., Nakashima, K. (2017). No associations between five polymorphisms in COMT gene and migraine. Acta Neurologica Scandinavica, 135 (2), 225-230. DOI: 10.1111/ane.12583.

Tammimaki, A., Mannisto, P.T. (2012). Catechol-O-methyltransferase gene polymorphism and chronic human pain: A systematic review and meta- analysis. Pharmacogenetics and Genomics, 22 (9), 673-691. DOI: 10.1097/FPC.0b013e3283560c46.

Tchivileva, I.E., Lim, P.F., Smith, S.B., Slade, G.D., Diatchenko, L., Mclean, S. a, Maixner, W. (2011). Effect of catechol-O-methyltransferase polymorphism on response to propranolol therapy in chronic musculoskeletal pain: a randomized, double-blind, placebocontrolled, crossover pilot study. Pharmacogenet Genomics, 20 (4), 239-248. DOI: 10.1097/FPC.0b013e328337f9ab.

Tompra, N., Van Dieen, J.H., Coppieters, M.W. (2016). Central pain processing is altered in people with Achilles tendinopathy. British Journal of Sports Medicine, 50 (16), 1004-1007. DOI: 10.1136/bjsports-2015-095476.

Toyama, K., Kiyosawa, N., Watanabe, K., Ishizuka, H. (2017). Identification of circulating miRNAs differentially regulated by opioid treatment. International Journal of Molecular Sciences, 18 (9). DOI: 10.3390/ijms18091991.

Van Ark, M., Rio, E., Cook, J., Van Den Akker-Scheek, I., Gaida, J.E., Zwerver, J., Docking, S. (2018). Clinical improvements are not explained by changes in tendon structure on ultrasound tissue characterization after an exercise program for patellar tendinopathy. American Journal of Physical Medicine and Rehabilitation, 97 (10), 708-714. DOI: 10.1097/PHM.0000000000000951.

van Esch, A.A.J., de Vries, E., te Morsche, R.H.M., van Oijen, M.G.H., Jansen, J. B.M.J., Drenth, J.P.H. (2011). Catechol-Omethyltransferase (COMT) gene variants and pain in chronic pancreatitis. Netherlands Journal of Medicine, 69 (7), 330-334.

Veluchamy, A., Hebert, H.L., Meng, W., Palmer, C.N.A., Smith, B.H. (2018). Systematic review and meta-analysis of genetic risk factors for neuropathic pain. Pain, 159 (5), 825-848. DOI: 10.1097/j.pain.0000000000001164.

Vick, J.S.,Askwith, C.C. (2015). ASICs and neuropeptides.Neuropharmacology, 94, 36-41. DOI: 10.1016/j.neuropharm.2014.12.012.

Vuoristo, M.M., Pappas, J.G., Jansen, V., Ala-Kokko, L. (2004). A stop codon mutation in COL11A2 induces exon skipping and leads to non-ocular stickler syndrome. American Journal of Medical Genetics, 130 A(2), 160-164. DOI: 10.1002/ajmg.a.30111.

Wang, L., Wei, C., Xiao, F., Chang, X., Zhang, Y. (2019). Influences of COMT rs4680 and OPRM1 rs1799971 Polymorphisms on Chronic Postsurgical Pain, Acute Pain, and Analgesic Consumption after Elective Cesarean Delivery. Clinical Journal of Pain, 35 (1), 31-36. DOI: 10.1097/AJP.0000000000000654.

Waxman, S.G., Merkies, I.S.J., Gerrits, M.M., Dib-Hajj, S.D., Lauria, G., Cox, J.J., Wood, J.N., Woods, C.G., Drenth, J.P.H., Faber, C.G. (2014). Sodium channel genes in pain-related disorders: phenotype-genotype associations and recommendations for clinical use. The Lancet Neurology, 13 (11), 1152-1160. DOI: 10.1016/S1474-4422(14)70150-4.

Zhang, X.Y., Wen, J., Yang, W., Wang, C., Gao, L., Zheng, L.H., Wang, T., Ran, K., Li, Y., Li, X., Xu, M., Luo, J., Feng, S., Ma, X., Ma, H., Chai, Z., Zhou, Z., Yao, J., Zhang, X., Liu, J.Y. (2013). Gain-of-Function mutations in SCN11A cause familial episodic pain. American Journal of Human Genetics, 93 (5), 957-966. DOI: 10.1016/j.ajhg.2013.09.016.

Zhou, L.L., Zhu, Y.M., Qian, F.Y., Yuan, C.C., Yuan, D.P., Zhou, X.P. (2018). MicroRNA-143-3p contributes to the regulation of pain responses in collagen-induced arthritis. Molecular Medicine Reports, 18 (3), 3219-3228. DOI: 10.3892/mmr.2018.9322.

Cite this article aS: Mkumbuzi, N.S., Posthumus, M., September, A.V., Collins, M. (2021). Genetic Variation as a Possible Explanation for the Heterogeneity of Pain in Tendinopathy: What can we learn from other pain syndromes? Central European Journal of Sport Sciences and Medicine, 4 (36), 57-72. DOI: 10.18276/cej.2021.4-06. 